\title{
Do Foreign-Owned Firms Provide More Formal Training Than Their Domestic Counterparts?
}

\author{
Merita Zulfiu Alili ${ }^{1}$
}

\begin{abstract}
Transition economies compete for FDI since it is expected to have net benefits for the host economy in terms of employment by creating jobs, paying higher wages, offering more training compared to the local firms, as well as benefits for the balance of payments, technology, growth and the alleviation of poverty. This paper examines if foreign-owned firms are more likely to provide formal training to their employees after controlling for other firm characteristics. This empirical analysis uses firm level data from the Business Environment and Enterprise Performance Survey (BEEPS) 2002-2009. To investigate the impact of foreign ownership on the provision of training this paper is using the Probit, Tobit and Craggit models. The empirical evidence presented in this paper indicates that foreign ownership has a positive and significant impact upon the incidence and intensity of training for both non-production and production workers using pooled cross-section data.
\end{abstract}

Keywords: FDI, provision of training, firm level data, Probit, Tobit, Craggit model

\section{Introduction}

One potential benefit associated with inward FDI is the development of the workforce's skills in the host country. Firms may choose to hire skilled employees from outside the firm, if available in the local market, or they can meet the demand for skilled labour by training their existing employees. Foreign-owned firms as a potentially important channel for the diffusion of new technologies and ideas are likely to have an increased demand for skills, and to accommodate this demand they may need to provide additional training for their employees. According to the technological change hypothesis, other things equal, a younger workforce, even though with less experience, is more likely to make a better use of the new technology than their older counterparts, since they have received their education more recently, i.e. their knowledge should be better matched with the capital equipment at work and they should be able to adapt more easily to new forms of work (Snower, 1999). Workers differ in skills, both because of their education qualifications and differences in work experience. Unskilled workers and those with less education will be more likely to work with older techniques and be paid less, while the better educated will be more likely to move to more modern techniques as innovation will be increasing. Accordingly, there will be an increased incentive for investing in education and training since it contributes to rising skill levels, which will partially offset the increase in wage inequality. Therefore, investing in education and training for workers may not only enable them to move from lower paid jobs to higher paid jobs, it may also shift the occupational structure of the economy by creating increased higher skilled jobs and fewer unskilled jobs, lowering wage inequality in the long-run. Snower (1996) addresses the 
mechanisms by which earnings differential encourage workers to acquire skills dependent upon the availability of good jobs. In Snower's model there are two types of workers, 'unskilled' or 'skilled' who live for two periods. The unskilled workers can only work at 'bad-jobs' with a marginal product $a_{\mathrm{u}}$, and the skilled workers are able to work at 'goodjobs' with a marginal product $a_{s}$, where $a_{s}>a_{u}$. 'Bad jobs' are considered those with low skill workers and low wages with little opportunity to accumulate human capital, whereas 'good jobs' require skilled workers and higher wages. The unskilled workers do not acquire education and are available to work in two periods, whereas skilled workers acquire education in the first period and are able to work in the second period providing skilled labour services. When workers decide to acquire education the training cost falls on them. However, after they find a skilled job the costs of education are shared between the employer and employee, since they earn higher wages compared to their potential earnings during the period they acquire education (wages for the skilled labour are higher than those for the unskilled labour).

Snower's model suggests that countries who offer little support for post-vocational education and training are likely to have a large proportion of unskilled workers and bad jobs. In this case firms have little incentive to offer good jobs since those vacancies will be difficult to be filled. As a result, workers have little incentive to invest in education. In contrast, in countries supporting education and endowed with skilled labour the free market will increase the incentive for workers to become more educated and skilled since there are many skilled jobs available. "A consequence is that economies can get stuck in a 'low-skill, bad-job' equilibrium, whereas seemingly similar economies maintain a 'high-skill, good-job' equilibrium...and relative earnings in labour markets may provide inadequate signals to individual educational decision makers" (Adnett and Davies, 1999, p. 227).

Almeida and Aterido (2008) examine the relation between training incidence and labour market regulations using firm level data across more than 65 developing countries. Their findings suggest that foreign firms are more likely to train their employees than domestic-owned firms and the higher the share of foreign ownership the more likely it is that firms offer training programmes. Oryshchenko (2011) use data from two rounds of the BEEPS (2002 and 2005) to study the relationship between training incidence and firm ownership. Citing both theoretical and empirical studies, Oryshchenko argues, as hypothesised above, that in order to meet the requirements of their more advanced technology foreign-owned firms have a higher propensity to train their employees to raise their skills. If the workforce in the host country is unskilled foreign-owned firms need to provide more training and if their local workers are already highly qualified it is less costly to train them further and they are likely to benefit more from providing training. Firms will engage more in training in more highly competitive markets to maintain their position, introducing new products by developing skills of their employees. Firms which are export-oriented are also more likely to be affected by international competition and hence, increase the quality of their products and services which are important determinants of training. In addition, the findings of Gashi and Adnett (2012) suggest that firms which have introduced new technology or production line are more likely to provide training to their employees and with a greater training intensity. In addition, Koch and Smolka (2017) argue that foreign-owned firms implement better technology than domestically owned firms and new and superior 
technology creates incentives for firms to enhance workforce skills (through both hiring of high-skilled workers and worker training). Analysing the within-firm skill changes caused by foreign acquisitions they find an increase in the relative demand for highskilled labor and a significant increase in worker training. Their findings imply that "worker training provides a direct and positive stimulus for the stock of human capital available in a country, with important implications for future innovation and growth", (p. 26). Workers that receive on-the job trainings and over time spent in the firm have a steeper wage profile and thus acquire a wage premium, providing empirical support for a firm-specific human capital acquisition explanation (Görg et al., 2007). Hence, the empirical evidence suggests that foreign-owned firms generally provide more training for their employees than their local counterparts. However, there is only limited evidence for transition countries and the following analysis adds to the knowledge about the effects of foreign ownership on the provision of training.

This paper will investigate how FDI affects the incidence of training in transition economies using the Business Environment and Enterprise Performance Survey (BEEPS) undertaken in three waves 2002, 2005 and 2009. The question to be addressed is whether foreign-owned firms are more likely to provide formal training for their employees in comparison to domestic-owned firms. Several measures of the provision of trainings are used: overall provision of formal training, provision of formal training to non-production employees and provision of training to production employees.

This chapter is organised in the following way. Section 2 describes the data and presents summary statistics for each measure of provision of training for both the pooled crosssection and panel data used in the study. The empirical strategy is presented in Section 3. Section 4 presents estimation results and section 5 concludes and summarises the paper's main findings.

\section{Data Description}

This empirical analysis uses firm level data from the Business Environment and Enterprise Performance Survey (BEEPS) 2002-2009. The survey was conducted by the European Bank of Reconstruction and Development (EBRD) in partnership with the World Bank Group covering information on firms' performance and examining the quality of the business environment in transition countries. These three waves use standardised questionnaires, though with some differences, and uniform sampling methods providing broadly comparable data.

In BEEPS 2005 and 2009 priority was given to respondents who participated in previous waves and had agreed to participate in future rounds of the BEEPS, hence creating a panel component. BEEPS 2002-2009 contains three cross-sections: 2002, 2005 and 2009 where we have a combination of pooled cross-section and panel data. For the pooled component only the group that was randomly selected in 2002, 2005 and 2009 is kept and the panel components are deleted to obtain a random sample and prevent the overrepresentation of these firms. Whereas for the panel component, only firms that participated in all three waves of the survey are included in the dataset, hence obtaining a balanced panel. Hence the pooled data now contains 6153 firms for 2002; 7691 firms for 2005 and 7773 for 2009 survey. The balanced panel data contains 374 firms for each wave (2002, 2005 and 2009), 
hence 1122 observations in total. Since pooled cross-section gives the highest number of observations the empirical analyses will be based on this group. Considering the advantages of panel data, that dataset is also used for a robustness check but keeping in mind that the number of observations is considerably smaller.

To investigate the impact of foreign ownership on the provision of training three measures of training are considered (Table 1). First, firms were asked if they had offered formal training programme to their permanent, full-time employees. Since this refers to formal training it is considered in this study as on-the-job training. However, using only this measure of training does not give information on the share of employees in each occupational category that received training over the previous fiscal year. Firms were also asked about the percentage of permanent production and non-production full-time employees that received formal training during the previous 12 months. Not all firms that answered the first question indicated the percentage of employees in each occupational category. Therefore, there are more observations in the variable TRAINING1 compared to variables TRAINING2 and TRAINING3.

Table 1. Summary of variables used in the empirical analyses

\begin{tabular}{lll}
\hline Variable label & $\begin{array}{l}\text { Variable } \\
\text { name }\end{array}$ & Variable definition \\
\hline Training & TRAINING1 & $\begin{array}{l}\text { Dummy variable equal to 1 if the firm provided formal training } \\
\text { programs for permanent, full-time employees in previous fiscal } \\
\text { year, 0 otherwise) }\end{array}$ \\
$\begin{array}{l}\text { Training of non- } \\
\text { production employees }\end{array}$ & TRAINING2 & $\begin{array}{l}\text { Percentage of permanent full-time non-production employees who } \\
\text { Training of }\end{array}$ \\
production employees & TRAINING3 & $\begin{array}{l}\text { Percentage of permanent full-time production employees who } \\
\text { received formal training in previous fiscal year }\end{array}$ \\
\hline
\end{tabular}

Figure 1 presents the share of non-production (TRAINING2) and production (TRAINING3) of employees that received formal training during the survey years 20022009, and suggests that firms, over the years, have increased the percentage of their employees receiving formal training and this percentage is higher for permanent full-time production employees.

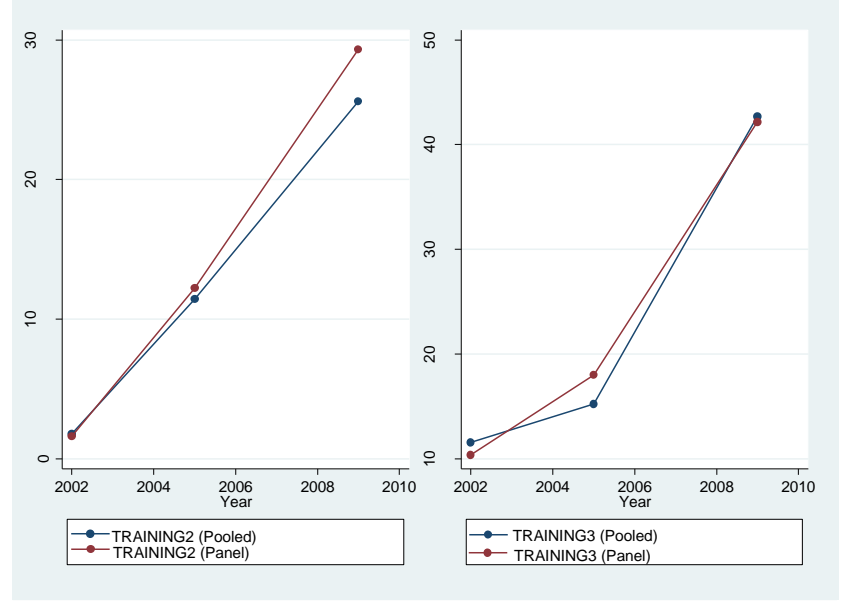

Figure 1. Changes in the share of nonproduction (TRAINING2) and production employees (TRAINING3) that received formal training during the survey years 2002-2009 
To analyse if the training measures vary across foreign-owned and domestic-owned firms the plot of the mean of TRAINING2 and TRAINING3 by ownership type and year are presented in Figure 2 for the pooled cross-section and Figure 3 for the panel data. Figure 2 suggests that the mean of the share of non-production and production employees are higher for foreign-owned firms over the period 2002-2009 as well as statistically significant (Table 2), whereas in the panel data the mean of training measures by ownership type and year is not statistically different (Table 2).

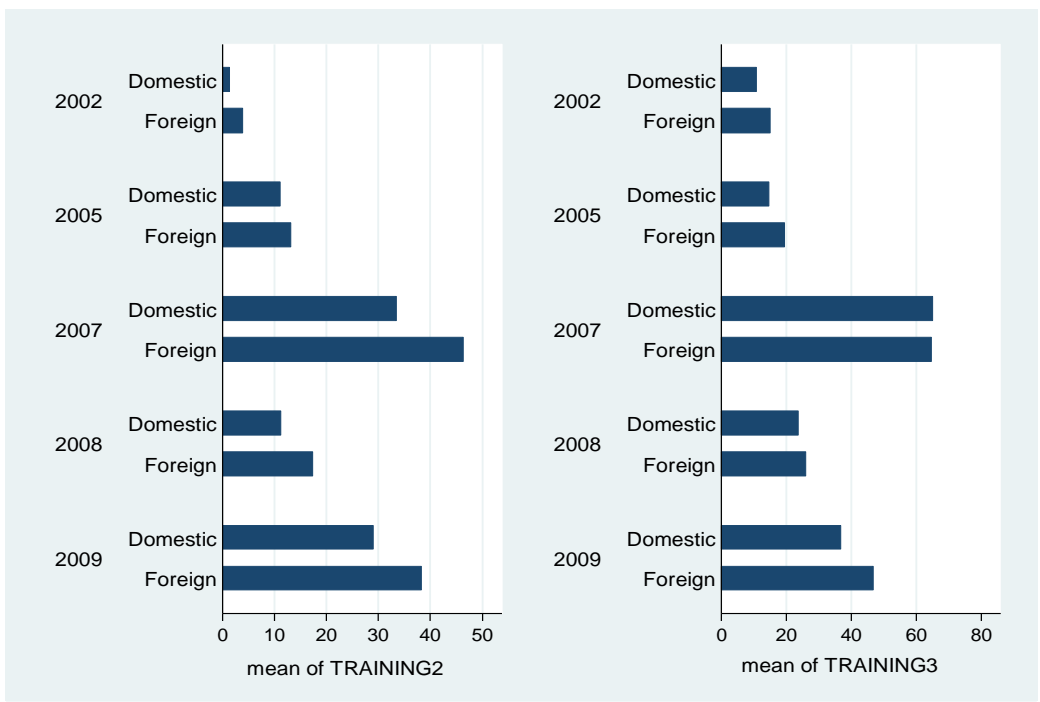

Figure 2. Mean of training measures by ownership (FOREIGN1) and year (Pooled 2002-2009)

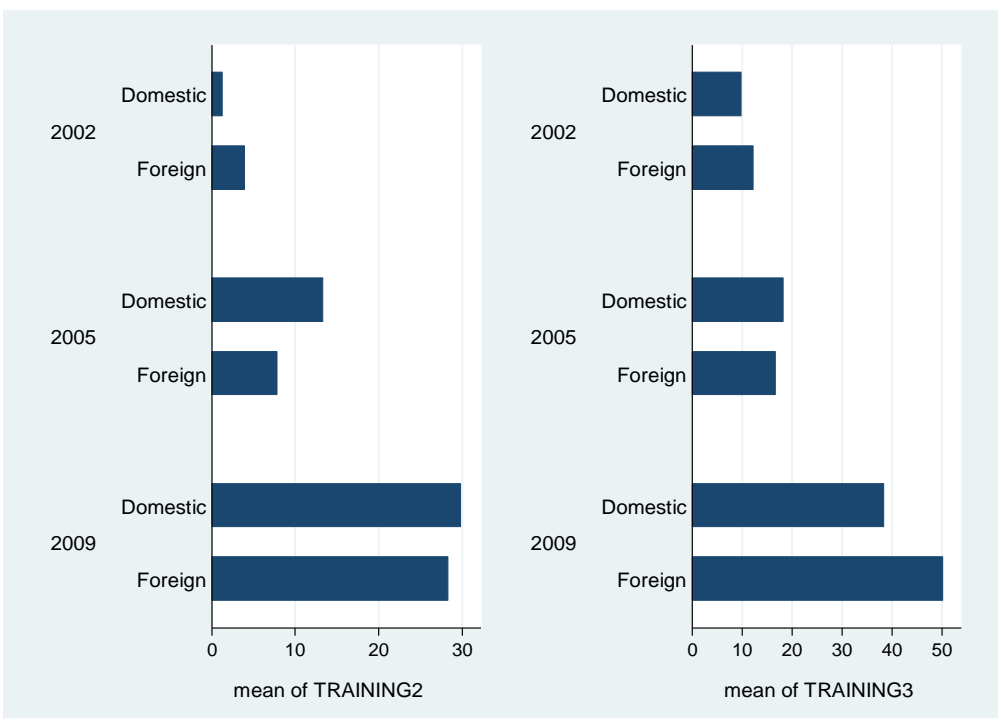

Figure 3. Mean of training measures by ownership (FOREIGN1) and year (Panel 2002-2009) 
Table 2. Test for statistical significance for the mean differences of training measures

\begin{tabular}{|c|c|c|c|c|c|c|c|c|}
\hline \multirow[b]{3}{*}{ Variables } & \multicolumn{4}{|c|}{ Pooled 2002-2009 } & \multicolumn{4}{|c|}{ Panel 2002-2009 } \\
\hline & $\begin{array}{l}t \text { test }(c \\
\text { Ho: dif } \\
\text { Mean }\end{array}$ & $\begin{array}{l}\text { iff }=m e \\
f=0 ; p\end{array}$ & $\begin{array}{l}\text { n (Dom.) } \\
\text { llues for } \mathrm{H}\end{array}$ & $\begin{array}{l}\text { ean(For.)) } \\
\text { liff } !=0\end{array}$ & $\begin{array}{l}t \text { test }(c \\
\text { Ho: di } \\
\text { Mean }\end{array}$ & $\begin{array}{l}\text { iff }=\mathrm{me} \\
f=0 ; p\end{array}$ & $\begin{array}{l}\text { n (Dom.) - } \\
\text { values for } \mathrm{H}\end{array}$ & $\begin{array}{l}\text { diff (For.) } !=0 \\
\text { diff }\end{array}$ \\
\hline & Dom. & For. & & & Dom. & For. & & \\
\hline TRAINING2 & 8.62 & 11.93 & $t=-4.13$ & $\mathrm{p}=0.000$ & 6.09 & 11.30 & $t=-1.98$ & $\mathrm{p}=0.048$ \\
\hline TRAINING3 & 16.42 & 20.81 & $t=-5.42$ & $\mathrm{p}=0.000$ & 15.52 & 19.92 & $t=-1.53$ & $\mathrm{p}=0.127$ \\
\hline
\end{tabular}

Hence, the descriptive analyses suggest that pooled cross-section and panel data do not differ much in terms of the behaviour of the share of non-production and production employees that received formal training. Nevertheless foreign-owned firms provide training to higher share of non-production and production employees compared to domestic-owned firms in the pooled cross-section data.

\section{Empirical Strategy}

According to the hypotheses developed above, foreign-owned firms should be more likely to provide training for their employees, hence indicating a positive effect on TRAINING1. If foreign-owned firms possess technological advantages and reallocate their activities in countries abundant with less-skilled workers and require skills which employees in the local market do not have they would have to train their employees, hence $\beta_{F}$ would be positive in relation to TRAINING2. If foreign-owned firm have a higher share of educated workers and more frequently upgrade their technology they would need to further train their employees to be able to use the new technology, thus expecting a positive sign of $\beta_{\mathrm{F}}$ in TRAINING3. The impact of foreign ownership on the provision of training is investigated through Equations 1 (a), (b) and (c).

TRAINING1 $1_{i t}=\alpha_{i t}+\beta_{F} F_{i t}+\beta_{T} T_{i t}+\beta_{E} E_{i t}+\beta_{I} I_{i t}+\beta_{S} S_{i t}+\beta_{A} A_{i t}+\beta_{C} C_{i t}+$ $+\beta_{\mathrm{Y}} \mathrm{Y}_{\mathrm{it}}+\beta_{E D U} E D U_{i t}+u_{i t} \quad$ (1(a)) TRAINING2 $2_{i t}=\alpha_{i t}+\beta_{F} F_{i t}+\beta_{T} T_{i t}+\beta_{E} E_{i t}+\beta_{I} I_{i t}+\beta_{S} S_{i t}+\beta_{A} A_{i t}+\beta_{C} C_{i t}+$ $+\beta_{\mathrm{Y}} \mathrm{Y}_{\text {it }}+\beta_{E D U} E D U_{i t}+u_{i t}$

TRAINING3 ${ }_{i t}=\alpha_{i t}+\beta_{F} F_{i t}+\beta_{T} T_{i t}+\beta_{E} E_{i t}+\beta_{I} I_{i t}+\beta_{S} S_{i t}+\beta_{A} A_{i t}+\beta_{C} C_{i t}+$ $\beta_{\mathrm{Y}} \mathrm{Y}_{\mathrm{it}}+\beta_{E D U} E D U_{i t}+u_{i t}$

Where $i$ represents the firm and $t$ the year when panel data is used; $a$ is an intercept term; $u_{i t}$ is an error term assumed to be uncorrelated with explanatory variables; whereas the variables included in the model are explained in Appendix 1. : Definition of variables used in the empirical analyses.

In addition to the control variables presented in the above models, the share of employees with tertiary education is also included as a control variable in the training models to test whether training is positively associated with the percentage of workers with university education. Next, we discuss the empirical methodology used in estimation of the above equations.

To estimate equation 1 (a) a Probit model is used with the dependent variable TRAINING1. The marginal effects after the Probit model are computed using $m f x$ command in Stata. 
Plotting the distribution of the dependent variables TRAINING2 and TRAINING3 (Figures 4 and 5) shows a large number of zero observations ${ }^{1}$. When the variable to be explained is non-negative, continuous above zero and has a lot of observations at zero, estimating the model using OLS may result in biased and inconsistent estimated parameter (Amemiya, 1984). Using the logarithm of the dependent variable in a linear regression is not an option since the $\log (0)$ is undefined (becoming a missing observation), while there is valuable information embedded in the zero observation responses. To address this problem the Tobit and Craggit models are used in such cases. Cragg (1971) suggests a two-tiered model which nests the usual Tobit model. The Tobit model is usually estimated by the maximum likelihood estimator, where the observations are divided into the censored observations and the observed positive values of the dependent variable. However, this model assumes that the same stochastic process determines both the value of the continuous dependent variable and the value of the discrete dependent variable. Wooldridge (2002, p.536) indicates that "an important limitation of the standard Tobit model is that a single mechanism determines the choice between $y=0$ versus $y>0$ and the amount of $y$ given $y>0$ ". Alternatives to the standard Tobit model allow the initial decision of $y>0$ versus $y=0$ to be treated separately from the decision of how much $y$ given that $y>0$, known as hurdle models or two-tiered models (Wooldridge, 2002). Cragg's model incorporates the Probit model in the first tier and truncated normal regression in the second tier which allows probability of a positive outcome and the value of a given positive outcome to be determined by separate processes.

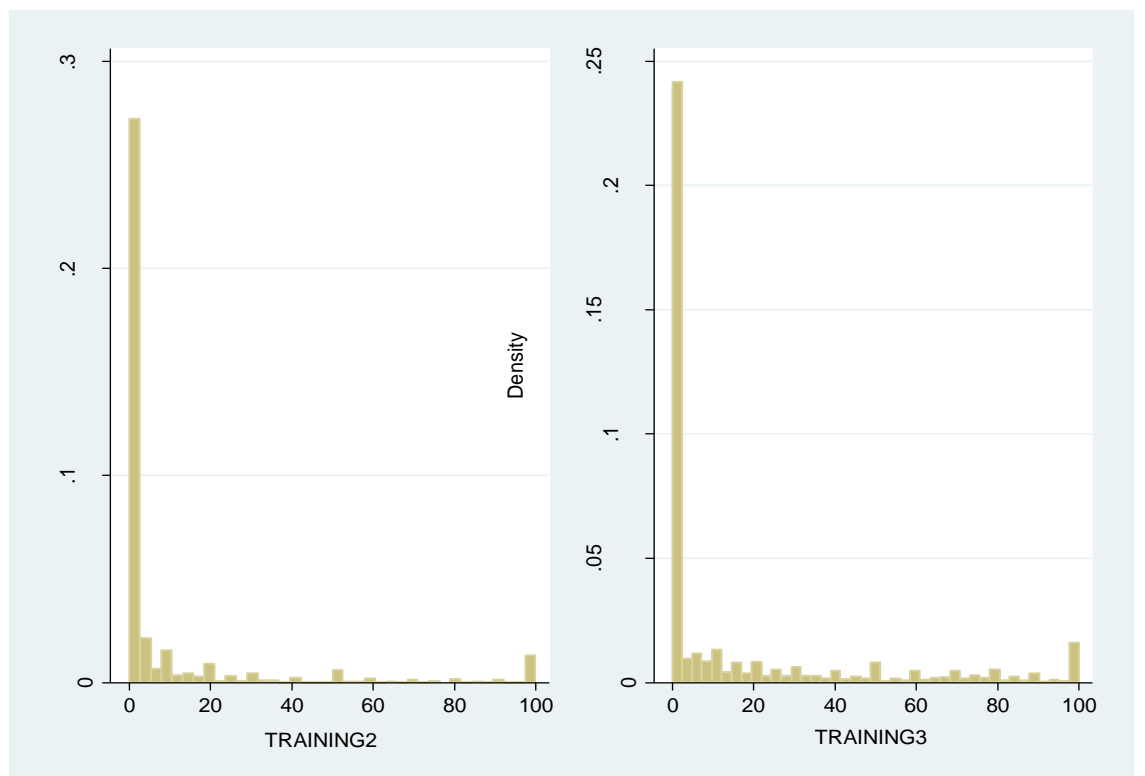

Figure 4. Distribution of dependent variables (Pooled 2002-2009)

1 The explanation of Graggit model is used from Zulfiu Alili, 2015. 


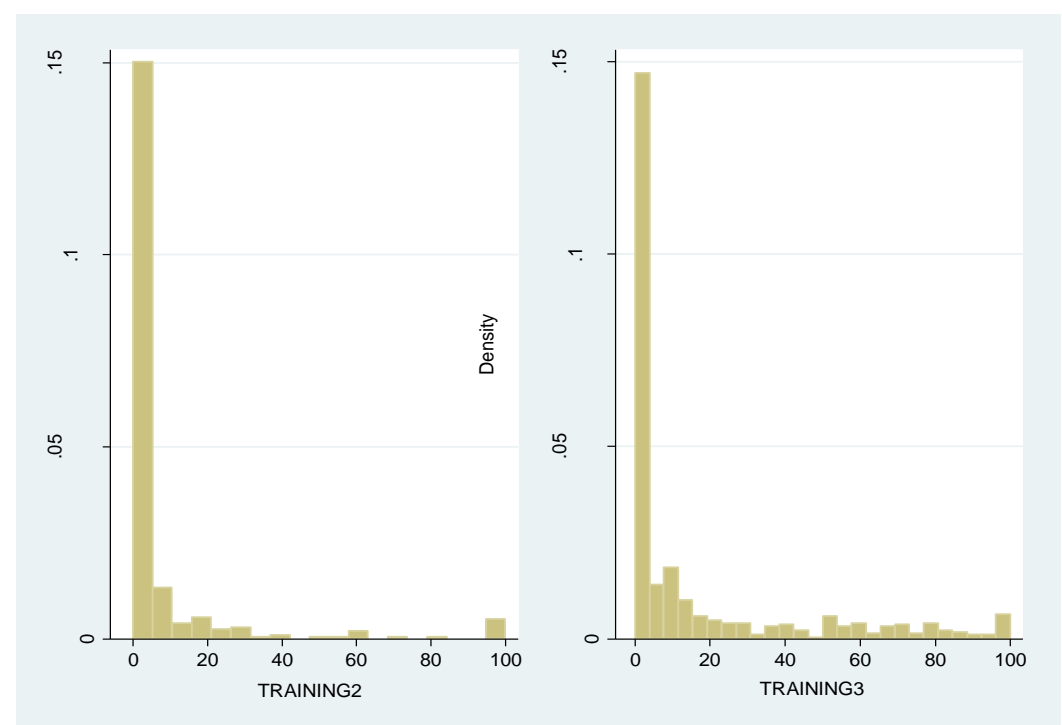

Figure 5. Distribution of dependent variables (Panel 2002-2009)

To test the assumption of the Tobit model that the residual is normally distributed with a constant variance the tobcm as well as bctobit tests for model specification are presented in Table 3 for pooled cross-section and Table 4 for panel data. The p-value equal to 0.000 for all specifications in the pooled cross section rejects the null hypothesis that the error terms are normally distributed. In addition, the LM statistic rejects the null suggesting that the Tobit specification is unsuitable for all models in pooled cross-section. Using panel data the conditional moment test fails to reject the null hypothesis that the error terms are normally distributes in both models, TRAINING2 and TRAINING3 (Table 4). The LM-statistic also supports the estimation of the Tobit model TRAINING2, but not the Tobit model TRAINING3. Thus the pooled cross-section models are estimated using the Craggit model, whereas the panel data models are estimated using both Tobit and Craggit models.

Table 3. Testing the linearity, normality and homoskedasticity assumptions of the Tobit specification-tobcm and bctobit for pooled cross-section data

\begin{tabular}{lll}
\hline tobcm conditional moment test & TRAINING2 & TRAINING3 \\
\hline FOREIGN1 & $\mathrm{CM}=404.79 ; \mathrm{p}>$ chi2 $=0.000$ & $\mathrm{CM}=775.35 ; \mathrm{p}>$ chi2 $=0.000$ \\
FOREIGN2 & $\mathrm{CM}=404.41 ; \mathrm{p}>$ chi2 $=0.000$ & $\mathrm{CM}=784.4 ; \mathrm{p}>$ chi2 $=0.000$ \\
FOREIGN1; FOREIGN2 & $\mathrm{CM}=400.26 ; \mathrm{p}>$ chi2 $=0.000$ & $\mathrm{CM}=775 ; \mathrm{p}>$ chi2 $=0.000$ \\
\hline bctobit LM-statistic & & \\
\hline FOREIGN1 & $\mathrm{LM}=1062.8 ; \mathrm{p}(5 \%)=3.723$ & $\mathrm{LM}=100.04 ; \mathrm{p}(5 \%)=4.082$ \\
FOREIGN2 & $\mathrm{LM}=1064.6 ; \mathrm{p}(5 \%)=3.466$ & $\mathrm{LM}=100.29 ; \mathrm{p}(5 \%)=3.776$ \\
FOREIGN1; FOREIGN2 & $\mathrm{LM}=1062.1 ; \mathrm{p}(5 \%)=3.395$ & $\mathrm{LM}=99.928 ; \mathrm{p}(5 \%)=3.870$ \\
\hline
\end{tabular}

\footnotetext{
${ }^{+} \mathrm{p}(5 \%)$ show the reported bootstrapped critical value at $5 \%$ significance level.
} 
Table 4. Testing the linearity, normality and homoskedasticity assumptions of the Tobit specification -tobcm and bctobit for panel data

\begin{tabular}{lll}
\hline tobcm conditional moment test & TRAINING2 & TRAINING3 \\
\hline FOREIGN1 & $\mathrm{CM}=2.396 ; \mathrm{p}>$ chi2 $=0.302$ & $\mathrm{CM}=3.462 ; \mathrm{p}>$ chi2 $=0.177$ \\
\hline bctobit LM-statistic & & \\
\hline FOREIGN1 & $\mathrm{LM}=7.296 ; \mathrm{p}(5 \%)=8.689$ & $\mathrm{LM}=11.885 ; \mathrm{p}(5 \%)=4.737$ \\
\hline
\end{tabular}

${ }^{\dagger} \mathrm{p}(5 \%)$ show the reported bootstrapped critical value at 5\% significance level.

\section{Estimation Results}

The marginal effects of the Probit model are reported in Table 5. For a foreignowned firm (FOREIGN1) the probability of providing formal training programs for their permanent and full-time employees increases by approximately 0.160 , holding other variables at their mean. FOREIGN2 and FOREIGN3 are also positively associated with training incidence, however the marginal effect is smaller than that for FOREIGN1. Results for panel data in relation to variables measuring foreign ownership the findings suggest FOREIGN1 is not significantly associated with training incidence, however there are only 72 foreign-owned firms which provided formal training to their full-time employees in the panel. Supporting theoretical predictions, the results suggest that firms which upgraded an existing product line are more likely to provide training in both pooled-cross section and panel data results (Table 5). Industry dummies suggest that firms in the sectors with higher level of technological sophistication of production are more likely to provide some formal training to their permanent full-time employees compared to firms in low-technology sectors (LOW_TECH), though the coefficient is significant only in the pooled cross-section. The evidence suggests that medium and large size firms are more likely to provide formal training programmes than small firms, though the marginal effect is bigger in large firms and consistent across both pooledcross section and panel data. In addition, older firms are more likely to provide formal training and the marginal effect is increasing with age of the firm. Country dummies indicate that CEE and SEE countries are more likely to provide training compared to CIS countries. In the panel data the year and age dummies were dropped because the number of observations fell to 42 , whereas in the pooled cross section the results imply that training incidence was higher in 2005 and lower in 2008 compared to 2002. This finding may suggest that firms in 2008 were less likely to train their employees as a result of the global financial crisis. Surprisingly, the coefficient of EDU ${ }^{2}$ is not statistically significant in all estimations. Possible explanations for this might be linked to the decrease in the percentage of labour force with tertiary education or inaccurate estimates of the percentage of employees with tertiary education reported by the managers.

\footnotetext{
2 We tried including an interaction term (EDU with FOREIGN1 and EDU with FOREIGN2), however the coefficients were not significant both in first and second Tier of Craggit model as well as in the Probit model.
} 
Table 5. Marginal effect of the Probit model (pooled cross-section and panel data)

\begin{tabular}{|c|c|c|c|c|c|c|}
\hline & Pooled & Pooled & Pooled & Panel & Panel & Panel \\
\hline & (1) & (2) & (3) & (4) & (5) & (6) \\
\hline VARIABLES & TRAINING1 & TRAINING1 & TRAINING1 & TRAINING1 & TRAINING1 & TRAINING1 \\
\hline FOREIGN1 & $\begin{array}{l}0.061 * * * \\
(0.014)\end{array}$ & & & $\begin{array}{l}0.047 \\
(0.061)\end{array}$ & & \\
\hline FOREIGN2 & & $\begin{array}{l}0.048^{* * *} \\
(0.013)\end{array}$ & $\begin{array}{l}-0.050 \\
(0.032)\end{array}$ & & $\begin{array}{l}-0.018 \\
(0.055)\end{array}$ & $\begin{array}{l}-0.122 \\
(0.137)\end{array}$ \\
\hline FOREIGN3 & & & $\begin{array}{l}0.001^{* * *} \\
(0.000)\end{array}$ & & & $\begin{array}{l}0.001 \\
(0.002)\end{array}$ \\
\hline OTHER & $\begin{array}{l}0.028 \\
(0.025\end{array}$ & $\begin{array}{l}0.027 \\
(0.024)\end{array}$ & $\begin{array}{l}0.029 \\
(0.025)\end{array}$ & $\begin{array}{l}-0.085 \\
(0.084)\end{array}$ & $\begin{array}{l}-0.092 \\
(0.084)\end{array}$ & $\begin{array}{l}-0.085 \\
(0.085)\end{array}$ \\
\hline TECH_UPGRADE & $\begin{array}{l}0.166^{* * * *} \\
(0.008)\end{array}$ & $\begin{array}{l}0.166^{* * * *} \\
(0.008)\end{array}$ & $\begin{array}{l}0.166^{* * * *} \\
(0.008)\end{array}$ & $\begin{array}{l}0.221^{* * *} \\
(0.041)\end{array}$ & $\begin{array}{l}0.220^{* * * *} \\
(0.041)\end{array}$ & $\begin{array}{l}0.219 * * * \\
(0.041)\end{array}$ \\
\hline EXPORTING & $\begin{array}{l}0.000^{* *} \\
(0.000)\end{array}$ & $\begin{array}{l}0.000^{* *} \\
(0.000)\end{array}$ & $\begin{array}{l}0.000^{*} \\
(0.000)\end{array}$ & $\begin{array}{l}0.000 \\
(0.001)\end{array}$ & $\begin{array}{l}0.000 \\
(0.001)\end{array}$ & $\begin{array}{l}0.000 \\
(0.001)\end{array}$ \\
\hline MED_LOW_TECH & $\begin{array}{l}0.046^{* * *} \\
(0.016)\end{array}$ & $\begin{array}{l}0.046^{* * *} \\
(0.016)\end{array}$ & $\begin{array}{l}0.045^{* * *} \\
(0.016)\end{array}$ & $\begin{array}{l}0.090 \\
(0.090)\end{array}$ & $\begin{array}{l}0.090 \\
(0.090)\end{array}$ & $\begin{array}{l}0.090 \\
(0.090)\end{array}$ \\
\hline MED_HIGH_TECH & $\begin{array}{l}0.116^{* * * *} \\
(0.019)\end{array}$ & $\begin{array}{l}0.116^{* * *} \\
(0.019)\end{array}$ & $\begin{array}{l}0.117^{* * *} \\
(0.019)\end{array}$ & $\begin{array}{l}0.128 \\
(0.089)\end{array}$ & $\begin{array}{l}0.126 \\
(0.089)\end{array}$ & $\begin{array}{l}0.135 \\
(0.090)\end{array}$ \\
\hline LESS_KNOWLEDGE & $\begin{array}{l}0.039 * * * \\
(0.011)\end{array}$ & $\begin{array}{l}0.040^{* * *} \\
(0.011)\end{array}$ & $\begin{array}{l}0.039 * * * \\
(0.011)\end{array}$ & $\begin{array}{l}0.081 \\
(0.050)\end{array}$ & $\begin{array}{l}0.074 \\
(0.050)\end{array}$ & $\begin{array}{l}0.072 \\
(0.051)\end{array}$ \\
\hline CONSTRUCTION & $\begin{array}{l}0.121^{* * * *} \\
(0.017)\end{array}$ & $\begin{array}{l}0.120^{* * *} \\
(0.017)\end{array}$ & $\begin{array}{l}0.120^{* * * *} \\
(0.017)\end{array}$ & & & \\
\hline TRANSPORT & $\begin{array}{l}0.059 * * * \\
(0.018)\end{array}$ & $\begin{array}{l}0.058^{* * *} \\
(0.018)\end{array}$ & $\begin{array}{l}0.060^{* * * *} \\
(0.018)\end{array}$ & & & \\
\hline MEDIUM & $\begin{array}{l}0.179 \text { *** } \\
(0.010)\end{array}$ & $\begin{array}{l}0.179^{* * *} \\
(0.010)\end{array}$ & $\begin{array}{l}0.179 * * * \\
(0.010)\end{array}$ & $\begin{array}{l}0.157^{\text {*** }} \\
(0.045)\end{array}$ & $\begin{array}{l}0.162^{* * *} \\
(0.046)\end{array}$ & $\begin{array}{l}0.164^{* * *} \\
(0.046)\end{array}$ \\
\hline LARGE & $\begin{array}{l}0.305^{* * *} \\
(0.012)\end{array}$ & $\begin{array}{l}0.305^{* * *} \\
(0.012)\end{array}$ & $\begin{array}{l}0.305^{* * *} \\
(0.012)\end{array}$ & $\begin{array}{l}0.325^{\text {*** }} \\
(0.051)\end{array}$ & $\begin{array}{l}0.336^{* * *} \\
(0.051)\end{array}$ & $\begin{array}{l}0.333^{* * *} \\
(0.051)\end{array}$ \\
\hline AGE2 & $\begin{array}{l}0.039 * * * \\
(0.013)\end{array}$ & $\begin{array}{l}0.039 * * * \\
(0.013)\end{array}$ & $\begin{array}{l}0.039 * * * \\
(0.013)\end{array}$ & & & \\
\hline AGE3 & $\begin{array}{l}0.063^{* * * *} \\
(0.016)\end{array}$ & $\begin{array}{l}0.062^{* * *} \\
(0.016)\end{array}$ & $\begin{array}{l}0.064 * * * \\
(0.016)\end{array}$ & & & \\
\hline CEE & $\begin{array}{l}0.169^{* * *} \\
(0.010)\end{array}$ & $\begin{array}{l}0.169^{* * *} \\
(0.010)\end{array}$ & $\begin{array}{l}0.168^{* * *} \\
(0.010)\end{array}$ & $\begin{array}{l}0.225^{* * *} \\
(0.044)\end{array}$ & $\begin{array}{l}0.229 * * * \\
(0.044)\end{array}$ & $\begin{array}{l}0.227 * * * \\
(0.044)\end{array}$ \\
\hline SEE & $\begin{array}{l}0.063^{* * *} \\
(0.014)\end{array}$ & $\begin{array}{l}0.064^{* * *} \\
(0.014)\end{array}$ & $\begin{array}{l}0.062^{* * * *} \\
(0.014)\end{array}$ & $\begin{array}{l}0.116^{* *} \\
(0.057)\end{array}$ & $\begin{array}{l}0.113^{* *} \\
(0.057)\end{array}$ & $\begin{array}{l}0.114^{* *} \\
(0.057)\end{array}$ \\
\hline y2005 & $\begin{array}{l}0.020^{* *} \\
(0.010)\end{array}$ & $\begin{array}{l}0.020^{* *} \\
(0.010)\end{array}$ & $\begin{array}{l}0.020^{* *} \\
(0.010)\end{array}$ & & & \\
\hline y2008 & $\begin{array}{l}-0.086^{* * * *} \\
(0.021)\end{array}$ & $\begin{array}{l}-0.087^{* * *} \\
(0.021)\end{array}$ & $\begin{array}{l}-0.087^{* * * *} \\
(0.021)\end{array}$ & & & \\
\hline y2009 & $\begin{array}{l}0.005 \\
(0.015)\end{array}$ & $\begin{array}{l}0.005 \\
(0.015)\end{array}$ & $\begin{array}{l}0.004 \\
(0.015)\end{array}$ & & & \\
\hline EDU & $\begin{array}{l}0.000 \\
(0.000)\end{array}$ & $\begin{array}{l}0.000 \\
(0.000)\end{array}$ & $\begin{array}{l}0.000 \\
(0.000)\end{array}$ & $\begin{array}{l}0.000 \\
(0.001)\end{array}$ & $\begin{array}{l}0.001 \\
(0.001)\end{array}$ & $\begin{array}{l}0.001 \\
(0.001)\end{array}$ \\
\hline Observations & 14875 & 14875 & 14875 & 751 & 751 & 751 \\
\hline
\end{tabular}

We next interpret the empirical findings of the Craggit model for training intensity using pooled cross-section data. Table 6 provides estimation results for training intensity, i.e. the percentage of non-production and production employees that undertook training in the previous fiscal year. The main variable of interest, foreign ownership (FOREIGN1), has a positive and significant coefficient in the first and second hurdle equation in pooled cross-section, suggesting that foreign-owned firms have a statistically significant influence upon the incidence and intensity of training. The coefficient of EDU is here positive and significant in the first hurdle equation of both models, TRAINING2 and 
TRAINING3, indicating that workers with tertiary education are more likely to receive training. Results of the second hurdle equation (Table 6, column 2 and 4) suggest that a higher percentage of workers with university education working as non-production workers undertake training, whereas a lower percentage of production workers with university education were undertaking training, which is also confirmed by the Tobit results for the panel data (Table 7 ).

Table 6. Estimation results of Craggit model for training intensity (pooled cross-section and panel data)

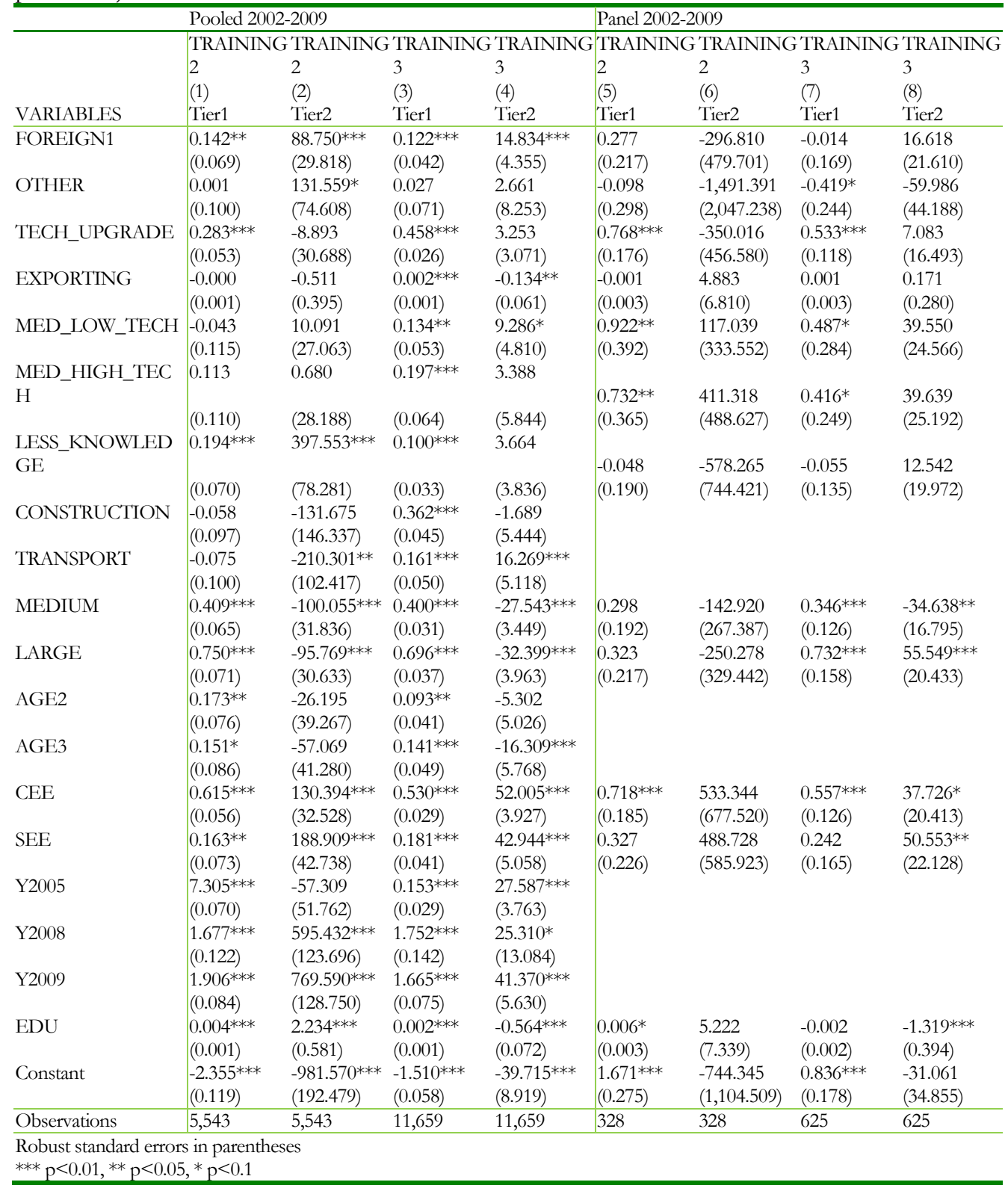


The Tobit results for the panel data (Table 7) imply that the foreign ownership coefficient (FOREIGN1) is not significant in both models, TRAINING2 and TRANING3. The marginal effect of TECH_UPGRADE indicates that on average, the firm that has upgraded an existing product line increases the percentage of nonproduction employees which receive formal training by 4.5 percentage points and the percentage of production employees receiving formal training by 5.8 percentage points. Industry dummies in the Tobit estimation support the Craggit results and suggest that firms in the group of medium high-technology and medium-low technology, on average, train more their non-production and production employees compared to firms in the group of low-technology. Country dummies imply that firms in CEE countries, on average, train their non-production employees by 6.9 percentage points more than firms in CIS countries, and increase the percentage of production employees which receive training by 8.1 percentage points in comparison to CIS countries. Firms in SEE countries also provide higher training intensity to their non-production and production employees compared to firms in CIS countries.

Table 7. Estimation results and marginal effect $(\mathrm{mfx})$ of the Tobit model for training intensity (panel data)

\begin{tabular}{|c|c|c|c|c|}
\hline & TRAINING2 & TRAINING2 & TRAINING3 & TRAINING3 \\
\hline VARIABLES & (1) & (2) $m f x$ & (3) & (4) $\mathrm{mfx}$ \\
\hline FOREIGN1 & $\begin{array}{l}-0.321 \\
(6.490)\end{array}$ & $\begin{array}{l}-0.086 \\
(1.732)\end{array}$ & $\begin{array}{l}0.468 \\
(5.917)\end{array}$ & $\begin{array}{l}0.159 \\
(2.018)\end{array}$ \\
\hline OTHER & $\begin{array}{l}-8.826 \\
(8.985)\end{array}$ & $\begin{array}{l}-2.211 \\
(2.105)\end{array}$ & $\begin{array}{l}-21.598^{* *} \\
(10.047)\end{array}$ & $\begin{array}{l}-6.409 * * \\
(2.589)\end{array}$ \\
\hline TECH_UPGRADE & $\begin{array}{l}17.490^{* * *} \\
(5.727)\end{array}$ & $\begin{array}{l}4.530^{* * * *} \\
(1.414)\end{array}$ & $\begin{array}{l}17.342^{* * *} \\
(4.498)\end{array}$ & $\begin{array}{l}5.811 * * * \\
(1.480)\end{array}$ \\
\hline EXPORTING & $\begin{array}{l}0.056 \\
(0.096)\end{array}$ & $\begin{array}{l}0.015 \\
(0.026)\end{array}$ & $\begin{array}{l}0.076 \\
(0.088)\end{array}$ & $\begin{array}{l}0.026 \\
(0.030)\end{array}$ \\
\hline MED_LOW_TECH & $\begin{array}{l}22.759 * * \\
(9.766)\end{array}$ & $\begin{array}{l}7.411 * * \\
(3.806)\end{array}$ & $\begin{array}{l}20.930 * * \\
(8.870)\end{array}$ & $\begin{array}{l}8.136^{* *} \\
(3.919)\end{array}$ \\
\hline MED_HIGH_TECH & $\begin{array}{l}36.959 \text { *** } \\
(9.791)\end{array}$ & $\begin{array}{l}13.681^{\text {*** }} \\
(4.819)\end{array}$ & $\begin{array}{l}17.117^{* *} \\
(8.374)\end{array}$ & $\begin{array}{l}6.478^{* *} \\
(3.515)\end{array}$ \\
\hline LESS_KNOWLEDGE & $\begin{array}{l}-7.170 \\
(5.784)\end{array}$ & $\begin{array}{l}-1.941 \\
(1.582)\end{array}$ & $\begin{array}{l}-1.408 \\
(5.084)\end{array}$ & $\begin{array}{l}-0.479 \\
(1.734)\end{array}$ \\
\hline MEDIUM & $\begin{array}{l}3.491 \\
(5.825)\end{array}$ & $\begin{array}{l}0.944 \\
(1.586)\end{array}$ & $\begin{array}{l}7.200 \\
(4.777)\end{array}$ & $\begin{array}{l}2.482 \\
(1.668)\end{array}$ \\
\hline LARGE & $\begin{array}{l}3.565 \\
(6.771)\end{array}$ & $\begin{array}{l}0.969 \\
(1.865)\end{array}$ & $\begin{array}{l}13.483^{* *} \\
(5.644)\end{array}$ & $\begin{array}{l}4.828 * * \\
(2.118)\end{array}$ \\
\hline CEE & $\begin{array}{l}24.052^{* * *} \\
(5.544)\end{array}$ & $\begin{array}{l}6.864 * * * \\
(1.651)\end{array}$ & $\begin{array}{l}22.708^{* * *} \\
(4.632)\end{array}$ & $\begin{array}{l}8.082^{* * *} \\
(1.718)\end{array}$ \\
\hline SEE & $\begin{array}{l}17.764 * * \\
(7.109)\end{array}$ & $\begin{array}{l}5.358^{* *} \\
(2.389)\end{array}$ & $\begin{array}{l}16.980^{* * *} \\
(6.012)\end{array}$ & $\begin{array}{l}6.290^{* * *} \\
(2.420)\end{array}$ \\
\hline EDU & $\begin{array}{l}0.210^{* *} \\
(0.094)\end{array}$ & $\begin{array}{l}0.056^{* *} \\
(0.025)\end{array}$ & $\begin{array}{l}-0.218^{* * *} \\
(0.081)\end{array}$ & $\begin{array}{l}-0.074 * * * \\
(0.028)\end{array}$ \\
\hline Constant & $\begin{array}{l}46.897 * * * \\
(9.485)\end{array}$ & & $\begin{array}{l}25.365^{* * *} \\
(7.026)\end{array}$ & \\
\hline Observations & 328 & & 625 & \\
\hline $\begin{array}{l}\text { Standard errors in paren } \\
* * * p<0.01, * * \mathrm{p}<0.05\end{array}$ & & & & \\
\hline
\end{tabular}

In sum, the empirical evidence of this paper indicates that foreign ownership has a positive and significant impact upon the incidence and intensity of training for both nonproduction and production workers using pooled cross-section data, however these 
results are not supported by the panel data. In addition, firms in high and medium-low technology provide more training for their non-production and production employees compared to low-technology firms. Firms in CEE and SEE countries, on average, provide higher training intensity for their non-production and production employees than their counterparts in CIS countries.

\section{Conclusion}

FDI is considered as an important instrument in the process of transition from a centrally planned to an open market economy. Transition economies compete for FDI since it is expected to have net benefits for the host economy in terms of employment by creating jobs, paying higher wages, offering more training compared to the local firms, as well as benefits for the balance of payments, technology, growth and alleviate poverty. These reasons have been used by governments to justify their policies attracting FDI. However, they do not usually consider the effects of FDI on the provision of training. This paper examines if foreign-owned firms are more likely to provide formal training to their employees after controlling for other firm characteristics. The empirical evidence in this paper suggests that foreign-owned firms are more likely to train both their nonproduction and production employees, so even if FDI goes to less-skill intensive sectors it will help improve the condition of less-skilled workers who will get increased training opportunities and their resulting increased productivity and wages should help to reduce inequality in the long term. These findings have important implications for the promotion of skill-biased technological change, suggesting that governments need to promote policies that will direct the FDI inflows to sectors where production could become more skill-intensive.

In addition, by promoting linkages between foreign and domestic-owned firms additional employment is created and further economic activity stimulated. Hence, government's policies encouraging inward FDI need to ensure that the benefits of FDI outweigh costs. Foreign-owned firms offer more training for both production and non-production workers than their local counterparts, but they should also be encouraged to train their low-skilled workers, which presents an element of corporate social responsibility if foreign firms are committed to increasing the benefits for all workers. Te Velde (2004) argues that governments may want to coordinate the market for skills by encouraging training in both foreign and domestic-owned firms. Since neither employers nor employees could capture all the benefits from training investments, governments may also support the cooperation between public research institutions and foreign-owned firms. Te Velde (2004) finds that firms invest in general training since they benefit from raising productivity more than wages so employees do not capture all benefits from training. Governments can encourage training within firms by expanding "the use of subsidies and tax breaks for foreign-owned firms, tax levies dedicated to supporting training, sharing the costs of training instructors, equipment or locations" (Te Velde, 2003 , p. 30). Hence, supporting a variety of public-private co-investments in worker training programs can be a promising solution. 


\section{References}

Adnett, N. and Davies, P. (1999). Schooling Quasi-Markets: Reconciling Economic and Sociological Analyses. British Journal of Educational Studies, vol. 47, no.3, pp. 221-234.

Almeida, R. and Aterido, R. (2008). The Incentives to Invest in Job Training: Do Strict Labor Codes Influence this Decision? SP Discussion Paper, no.0832.

Amemiya, T. (1984). Tobit Models: A Survey. Journal of Econometrics, no. 24, pp. 3-61.

Cragg, J. (1971). Some Statisticall Models for Limited Dependent Variables with Application to the Demand for Durable Goods. Econometrica, vol. 39, no. 5.

Gashi A. and Adnett N. (2012). Technology, training and transition: evidence from the Western Balkans. Eastern European Economics, vol. 50, no. 6, pp57-80.

Görg, H., Strobl, E. and Walsh, F. (2007). Why Do Foreign-Owned Firms Pay More? The Role of On-theJob Training. Review of World Economics, vol. 143, issue 3, pp. 464-482.

Koch, M. and Smolka, M. (2017). Foreign Ownership and Skill-biased Technological Change. University of Bayreuth, Aarbus University, Germany, Denmark.

Oryshchenko, V. (2011). Essays in Econometrics. Girton College and Faculty of Economics, University of Cambridge.

Snower, D. (1996). The Low-Skill, Bad-Job Trap. Chapter 6. Booth, A. and Snower, D. (eds.) Acquiring Skills: Market Failures, Their Symptoms and Policy Responses. The Centre for Economic Policy Research. University Press, Cambridge, pp. 111-124.

Snower, D. (1999). Causes of Changing Earnings Inequality. IZA Discussion Paper, no. 29.

Te Velde, D. W. (2004). Regional Integration and Foreign Direct Investment in Developing Countries. This paper forms part of a larger DFID/EC-PREP funded research project on Regional Integration and Poverty.

Te Velde, D.W. (2003). Foreign Direct Investment and Income Inequality in Latin America. Overseas Development Institute, London.

Wooldridge, J. (2002). Econometric Analysis of Cross Section and Panel Data. MIT Press, USA.

Zulfiu Alili, Merita (2015). An Empirical Investigation of the Effects of Foreign Direct Investment on the Skill Intensity of Host Country Employment. Procedia Economics and Finance, vol. 26, pp. 623-629.

Appendix 1. Definition of variables used in the empirical analyses

Variable label Variable name Variable definition

Ownership FOREIGN1

FOREIGN2

OTHER

Degree of FOREIGN3

foreign

ownership

Technology TECH_UPGRADE upgrade

$\mathrm{R} \& \mathrm{D} \& \mathrm{D}$
Foreign firms are defined as firms with $51 \%$ or more foreign ownership (Dummy variable equal to 1 if the firm is foreign-owned, 0 otherwise

Foreign firms are defined as firms with $10 \%$ or more foreign ownership (Dummy variable equal to 1 if the firm is foreign-owned, 0 otherwise)

Dummy variable equal to 1 if the firm is $51 \%$ or more with 'other' ownership, 0 otherwise

Degree of foreign ownership= FOREIGN2 $\mathrm{x}$ FOREIGN PERCENTAGE, where

FOREIGN PERCENTAGE is the percentage of firm owned by private foreign individuals, companies or organizations

Dummy variable equal to 1 if the firm has upgraded an existing product line/service in previous 3 years, 0 otherwise

Amount spent on research and development in previous fiscal year (US \$)

Percentage of firm's sales that were direct exports 


\begin{tabular}{|c|c|c|}
\hline \multirow[t]{6}{*}{$\begin{array}{l}\text { Industry } \\
\text { dummy }\end{array}$} & LOW_TECH & $\begin{array}{l}\text { Low-technology: Other manufacturing; Food; } \\
\text { Textiles; Garments (18 \& 23); }\end{array}$ \\
\hline & MED_LOW_TECH & $\begin{array}{l}\text { Medium low-technology: Plastics \& rubber; Non } \\
\text { metallic mineral products; Basic metals; Fabricate } \\
\text { metal products }\end{array}$ \\
\hline & MED_HIGH_TECH & $\begin{array}{l}\text { Medium high-technology: Chemicals; Machinery } \\
\text { and equipment; Electronics ( } 31 \& 32)\end{array}$ \\
\hline & LESS_KNOWLEDGE & $\begin{array}{l}\text { Less-knowledge-intensive market services: Other } \\
\text { services; Wholesale; Retail; Hotel and restaurants: } \\
\text { section H }\end{array}$ \\
\hline & CONSTRUCTION & Construction Section F \\
\hline & TRANSPORT & $\begin{array}{l}\text { Transport: Transport Section I: }(60,61,62) \text {; IT } \\
\text { (72) }\end{array}$ \\
\hline Size & $\begin{array}{l}\text { SMALL } \\
\text { MEDIUM } \\
\text { LARGE }\end{array}$ & $\begin{array}{l}\text { Dummies for size of the firm: small }(<20 \\
\text { employees); medium(20-99 employees); large }(100 \\
\text { and over employees) }\end{array}$ \\
\hline Age & $\begin{array}{l}\text { AGE }<5 \\
\text { AGE } 5 \text { to } 15 \\
\text { AGE }>15\end{array}$ & $\begin{array}{l}\text { Dummies for age of the firm: less than } 5 \text { years, } 5 \\
\text { to } 15 \text { years, more than } 15 \text { years }\end{array}$ \\
\hline \multirow[t]{3}{*}{ Country } & CIS & $\begin{array}{l}\text { Dummies for country groups } \\
\text { Armenia; Azerbaijan; Belarus; Georgia; Kazakhstan; } \\
\text { Kyrgyzstan; Moldova; Russia; Tajikistan; Ukraine; } \\
\text { Uzbekistan. }\end{array}$ \\
\hline & $\mathrm{CEE}$ & $\begin{array}{l}\text { Bulgaria; Czech Republic; Estonia; Hungary; Latvia; } \\
\text { Lithuania; Poland; Romania; Slovakia; Slovenia }\end{array}$ \\
\hline & SEE & $\begin{array}{l}\text { Albania; Bosnia and Herzegovina; Croatia; } \\
\text { Macedonia (FYROM); Montenegro; Serbia }\end{array}$ \\
\hline Year & YEAR & $\begin{array}{l}\text { Dummies for the year of the survey (Pooled cross- } \\
\text { section: 2002; 2005; 2007; 2008; 2009. Panel data: } \\
\text { 2002; 2005; 2009) }\end{array}$ \\
\hline $\begin{array}{l}\text { University } \\
\text { education }\end{array}$ & EDU & $\begin{array}{l}\text { Percentage of employees at the end of fiscal year } \\
\text { with a university degree }\end{array}$ \\
\hline
\end{tabular}

